\title{
Quality and Drying Kinetics of Moringa (Moringa oleifera Lam.) Seed Flour After Drying Process
}

\author{
Francisco Marto de Souza \\ Federal Rural University of Pernambuco, Postgraduate Program in Soil Science, Recife, \\ Pernambuco / Brazil. E-mail: francisco.marto@hotmail.com

\section{Emmanuel Moreira Pereira} \\ São Paulo State University (Unesp), School of Agricultural and Veterinarian Sciences, \\ Jaboticabal / São Paulo / Brazil. E-mail: emmanuel16mop@ hotmail.com
}

\section{Jackson Silva Nóbrega (Corresponding author)}

Federal University of Paraiba, Center of Agrarian Sciences, Graduate Program in Agronomy, Areia / Paraíba / Brazil. E-mail: jacksonnobrega@ hotmail.com

\section{Rosilene Agra da Silva}

Federal University of Campina Grande, Agro-Food Science and Technology Center, Pombal / Paraíba / Brazil. E-mail: rosileneagra@ hotmail.com

\section{Adriana da Silva Santos}

Federal University of Paraiba, Center of Agrarian Sciences, Graduate Program in Agronomy, Areia / Paraíba / Brazil. E-mail: drica_pl@ hotmail.com

\section{Ellen Caroline Santos Lima}

Federal University of Campina Grande, Agro-Food Science and Technology Center, Pombal / Paraíba / Brazil. E-mail: ellencaroline.sl@ hotmail.com

\section{José Sidnaldo Pinsetta Junior}

São Paulo State University (Unesp), School of Agricultural and Veterinarian Sciences, Jaboticabal / São Paulo / Brazil. E-mail: j.pinsetta@gmail.com 


\author{
Vanessa Karla Santos de Miranda \\ Postgraduate Course in Applied Nutrition Phytotherapy - FOA. E-mail: \\ vanessamiranda.nutri@outlook.com
}

\begin{abstract}
Alfredina dos Santos Araújo
Federal University of Campina Grande, Agro-Food Science and Technology Center, Pombal /

Paraíba / Brazil. E-mail: alfredina@ccta.ufcg.edu.br
\end{abstract}

Received: Nov. 24, 2019

doi:10.5296/jas.v8i2.15888
Accepted: Feb. 17, 2019 Published: Feb. 25, 2019

URL: https://doi.org/10.5296/jas.v8i2.15888

\begin{abstract}
The moringa presents great nutritional value thanks to its bioactive compounds, providing many benefits to human health. Therefore, this plant has been studied with the aim of being used as a food fortifier. The objective of this work was to describe the technological process in the production of moringa seed flour at different temperatures through numerical and analytical solutions and assess its final chemical quality. Moringa pods were obtained in experimental area and were treated by removing their seeds. A drying process was performed at different temperatures $\left(40,50,60^{\circ} \mathrm{C}\right)$ with progressive weighing on a semi-analytical scale until constant weight which was obtained after 2 hours of drying. The flour was obtained with the use of a knife mill. Empirical models of Lewis, Herdenson and Pabis, Peleg and Page were used to describe the dehydration curve of moringa seeds. Protein, lipid, carbohydrate, ash and moisture contents were determined in the flours obtained at different temperatures. We verified that best fit model was Page's, representing the best coefficients of determination and chi-squares. The Peleg model showed incoherent behavior, indicating that it is not ideal for simulating the drying process of moringa seeds at the studied temperatures. The temperature influenced the quality of the flour. The flour obtained at a temperature of $40{ }^{\circ} \mathrm{C}$ showed the best percentages of protein, ash, moisture and carbohydrates. For the lipid content, the best flour results was obtained at temperatures of 50 and $60{ }^{\circ} \mathrm{C}$.
\end{abstract}

Keywords: centesimal composition, mathematical models, Moringa oleifera lam, temperature

\title{
1. Introduction
}

The moringa (Moringa oleifera Lam.), is a native species of India, presenting high adaptability to edaphoclimatic conditions of semi-arid regions (Souza et al., 2018). This is the most cultivated specie of the Moringaceae family (Páramo-Calderón et al., 2019). 
The moringa is an important alternative for small producers, and can be used as a source of human food, water purifier, traditional medicine and as oil source (Nóbrega et al., 2018). In addition, moringa presents potential for use in animal feed, especially during periods of drought (Gualberto et al., 2014).

M. oleifera leaves high levels of phytochemicals such as phenolic compounds (chlorogenic acid, gallic acid, kaempferol and quercetin glycosides) and $\beta$-carotene and ascorbic acid that promote human health benefits, such as anti-radical activity and different bioactivities (Rodrígues-Pérez et al., 2015; Vázquez-León et al., 2017).

Forage produced from the moringa is a good source of proteins, containing $25,1 \%$ total protein in the dry mass, considered a high value of high quality protein, and digestibility of 79\% (Obando and Ojeda, 2016).

The moringa seed flour is used in animal feed because it is nutritionally rich, being a seed of easy acquisition and production and producing a large vegetable mass during the year (Anwar et al., 2007). According to Abiodun et al., (2012), evaluating the physicochemical properties of defatted bran from moringa seeds, it was found that it is rich in ash, crude fiber, crude protein and carbohydrates, showing a potential to be used in human and animal diets due to the high protein content.

The drying process of a product consists of the transfer of heat and mass between the drying air and the material to be dried, where raising the temperature results in an increase in the vapor pressure in the material, resulting in the reduction of the water content (Mercali et al., 2010). The use of mathematical models is an important tool for estimating the time required reducing the water content of a product, and the need to adjust mathematical models to the experimental data is undeniable (Kashaninejad et al., 2007).

The use of mathematical models in the description of the drying process aims to optimize the technological process of flour production. The models are based on external variables of product, such as temperature and relative humidity of drying air (Sousa et al, 2011).

The objective of this work was to describe the technological process in the production of $M$. oleifera Lam., seed flour at different temperatures by means of numerical and analytical solutions, and determining its final chemical quality.

\section{Materials and Methods}

\subsection{Experiment Site}

This study was carried out at the Center of Sciences and Food Technology - CCTA, Pombal, belonging to the Federal University of Campina Grande (UFCG), Brazil (06 46'13' 'S, $37^{\circ} 48^{\prime} 06^{\prime \prime} \mathrm{W}$ and $\sim 242 \mathrm{~m}$ of altitude).

\subsection{Plant Material}

Moringa seeds were harvested manually from parent plants free of the presence of pests and diseases, located in the CCTA / UFCG. The processing and classification of the seeds 
occurred on the same day after the harvest, using those that were visibly healthy. The initial moisture of the seeds before the experiment was $6 \%$.

\subsection{Flour Production}

After seeds removal from fruits, they were cleaned, removing the dirt adhered to their surface and dried in oven with air circulation and forced renovation (Solab TM, model SL 102/42) in three different temperatures $\left(40,50,60{ }^{\circ} \mathrm{C}\right)$. The material was placed in cast stainless steel forged trays measuring $15 \mathrm{~cm}$ in length, $10 \mathrm{~cm}$ in thickness and $5 \mathrm{~cm}$ in depth. In each tray was used around $50 \mathrm{~g}$ of plant material, previously weighed in a semi-analytical balance $\left(\right.$ Bell $^{\circledR}$ - Model SSR-600, with 0,05-g accuracy), three repetitions were used for each temperature. The weighings were carried out continuously, counting from time 0 until reaching constant weight. The moisture content data of the moringa seeds were determined according to IAL (2008).

\subsection{Kinetics of Drying}

For the adjustment of the experimental data the software LAB fit curve fitting (Silva and Silva, 2016) was used. The adjustment of the mathematical models to the curves of dehydration of the moringa seeds to the experimental data was done using the empirical equations described in Table 1.

The evaluation criteria of the drying kinetics used to choose the models were the coefficients of determination $\left(\mathrm{R}^{2}\right)$ and the chi-square $(\quad)$, calculated by Equation 1 .

$$
\chi^{2}=\sqrt{\sum\left(X_{\text {exp }}^{*}-X_{\text {pre }}^{*}\right)^{2}}
$$

where:

chi-square;

$\mathrm{X}_{\mathrm{exp}}^{*}$ - experimental moisture ratio by the model;

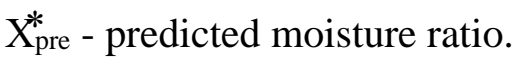

\subsection{Chemical Analysis}

After drying, the samples were ground with the aid of a willey-type mill with the opening of meshes 10, 20, $32(1,70 \mathrm{~mm}, 0,85 \mathrm{~mm}, 0,50 \mathrm{~mm})$ and analyzed for the content of:

Humidity (\%): The percentage of humidity was determined by means of oven drying at $100 \pm$ $5{ }^{\circ} \mathrm{C}$ for 24 hours (IAL, 2008).

Ash (\%): It was determined by the incineration of the sample in muffle at $550{ }^{\circ} \mathrm{C}$ until the ashes were white or slightly grayish (IAL, 2008).

Proteins (\%): The total nitrogen content of the samples was determined by the Micro-Kjeldahl method, using the generic conversion factor 6.25 for transforming the quantified protein content (IAL, 2008). 
Lipids (\%): It was determined by the Soxhlet method, based on the extraction of lipids into fats and fatty substances, which are defined as food components that are insoluble in water and soluble in organic solvents, such as ethyl ether, petroleum, acetone, chloroform, benzene and alcohols. As described by IAL (2008).

Carbohydrates (\%): It was estimated by the difference between $100 \%$ and the sum of the percentages of the other components of the sample (IAL, 2008).

\subsection{Statistical Analysis}

The design was completely randomized (DIC). The comparison between treatments was performed using analysis of variance (ANOVA). The results were compared by the Tukey test at $5 \%$ significance in order to observe if there was a significant difference between the treatments. The statistical results were analyzed by the ASSISTAT ${ }^{\circledR}$ program (Silva and Azevedo, 2016).

\section{Results and Discussion}

\subsection{Drying Kinetics of Seeds}

Table 2 shows the parameters obtained from the adjustments of the Henderson and Pabis, Lewis, Page and Peleg models, as a function of the drying of the moringa (Moringa oleifera Lam.) seeds, at temperatures of 40,50 , and $60^{\circ} \mathrm{C}$.

Table 1. Empirical models used to describe the amount of water in moringa seeds

\begin{tabular}{llll}
\hline Model & Name & Empirical Expression & Reference \\
\hline 1 & Lewis & $\mathrm{RX}=\exp \left(-\mathrm{a} \mathrm{t}^{\mathrm{b}}\right) \sigma \mathrm{e}^{-\mathrm{at}}$ & Jittanit, 2011 \\
2 & Henderson and Pabis & $\mathrm{RX}=\mathrm{a} \exp (-\mathrm{k} \mathrm{t})$ & Sousa et al., 2011 \\
3 & Peleg & $\mathrm{RX}=1-\mathrm{t} /(\mathrm{a}+\mathrm{bt})$ & Mercali et al, 2010 \\
4 & Page & $\mathrm{RX}=\exp \left(-\mathrm{k} \mathrm{t} \mathrm{t}^{\mathrm{n}}\right)$ & Kashaninejad et al., 2007 \\
\hline
\end{tabular}

RX - Moisture rate, dimensionless; T - Drying time, h; K, ko, k1 - Drying constants, h-1; a, b, c, n- Coefficient of the models; Source: Pereira et al. (2017a).

The parameters of the models adjusted to the experimental data of the water quantity kinetics during the drying of the moringa seed were verified the good representation of the Page model, which obtained the highest coefficients of determination $\left(R^{2}\right)$, varying from 0,9197 to 0,9935 and the smaller chi-squares ( ), from 0,1618 to 0,2075 (Table 2). 
Table 2. Adjustment parameters of the experimental models to the moringa (Moringa oleifera Lam.) seed drying data at temperatures of $40,50,60{ }^{\circ} \mathrm{C}$

\begin{tabular}{|c|c|c|c|c|}
\hline \multicolumn{5}{|c|}{ Hendeson e Pabis } \\
\hline \multirow{2}{*}{ Temperature $\left({ }^{\circ} \mathrm{C}\right)$} & \multicolumn{2}{|c|}{ Parameters } & \multirow{2}{*}{$\mathrm{R}^{2}$} & \\
\hline & $\mathrm{a}$ & $\mathrm{b}$ & & \\
\hline 40 & 0.8947 & 0.3599 & 0.9614 & 0.3927 \\
\hline 50 & 0.8624 & 0.1642 & 0.8485 & 0.2761 \\
\hline 60 & 0.9731 & 0.1028 & 0.9882 & 0.1059 \\
\hline \multicolumn{5}{|c|}{ Lewis } \\
\hline \multirow{2}{*}{ Temperature $\left({ }^{\circ} \mathrm{C}\right)$} & \multicolumn{2}{|c|}{ Parameters } & \multirow{2}{*}{$\mathrm{R}^{2}$} & \\
\hline & $\mathrm{a}$ & $\mathrm{b}$ & & \\
\hline 40 & 0.4210 & - & 0.9616 & 0.5689 \\
\hline 50 & 0.2016 & - & 0.8281 & 0.3286 \\
\hline 60 & 0.1057 & - & 0.9886 & 0.1138 \\
\hline
\end{tabular}

\begin{tabular}{|c|c|c|c|c|}
\hline \multicolumn{5}{|c|}{ Page } \\
\hline \multirow{2}{*}{ Temperature $\left({ }^{\circ} \mathrm{C}\right)$} & \multicolumn{2}{|c|}{ Parameters } & \multirow{2}{*}{$\mathrm{R}^{2}$} & \\
\hline & $\mathrm{a}$ & $\mathrm{b}$ & & \\
\hline 40 & 0.1071 & 0.7125 & 0.9901 & 0.2037 \\
\hline 50 & 0.1212 & 0.7579 & 0.9197 & 0.2075 \\
\hline 60 & 0.1699 & 0.8065 & 0.9935 & 0.1618 \\
\hline \multicolumn{5}{|c|}{ Peleg } \\
\hline \multirow{2}{*}{ Temperature $\left({ }^{\circ} \mathrm{C}\right)$} & \multicolumn{2}{|c|}{ Parameters } & \multirow{2}{*}{$\mathrm{R}^{2}$} & \\
\hline & $\mathrm{a}$ & $\mathrm{b}$ & & \\
\hline 40 & 0.1559 & 0.8881 & 0.9772 & 0.2398 \\
\hline 50 & 0.4891 & 0.6180 & 0.8527 & 0.3069 \\
\hline 60 & 0.6163 & 0.8825 & 0.9927 & 0.6223 \\
\hline
\end{tabular}

$\mathrm{R}^{2}=$ determination coefficient; $\quad=$ chi-square; $\mathrm{a}$ and $\mathrm{b}=$ coefficients of the mode. Source: 
Pereira et al. (2017a)

These results show a good fit to the drying curve as presented in Figure 1, higher than that obtained by the other models. Considering the same criteria, we have the models of Henderson and Pabis (Fig 2) and Lewis (Fig 3) with good representation to the experimental points of the drying curve with $R^{2}$ above 0.82 and below 0,6 (Table 1). It was found that in the Page model it presented a progressive increase due to the temperature increase, for the constant $a$ and $b$. This result points to the high affinity of the model with the experimental data, indicating that it can be used in the drying process in moringa seeds with high reliability on the drying temperatures. Corroborating with this study, Madureira et al. (2012), working with drying of the pulp of fig, at temperatures of 50,60 and $70{ }^{\circ} \mathrm{C}$, using the Lewis, Page, Henderson and Pabis models showed good affinity of these models to the experimental data, with $\mathrm{R}^{2}$ above 0.8 and can be used in the prediction of drying kinetics at temperatures of 50 , 60 and $70{ }^{\circ} \mathrm{C}$. Similar behavior with this study was also evidenced by Pereira et al. (2017) describing kinetics of drying palm shoots at different temperatures $\left(50,60,70\right.$ and $\left.80{ }^{\circ} \mathrm{C}\right)$ using the empirical models of Lewis, Henderson and Pabis, Wang and Singh, Peleg. The Peleg and Wang and Singh models showed a unique graphic behavior, reaching the field of negative water content before reaching the equilibrium point of the dehydration process, demonstrating that the models are not capable of simulating the drying process. 

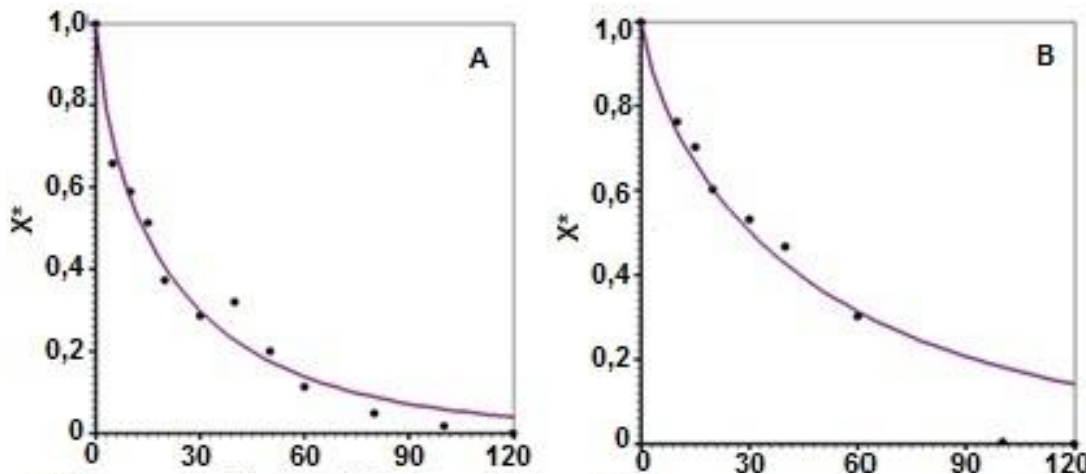

2020, Vol. 8, No. 2
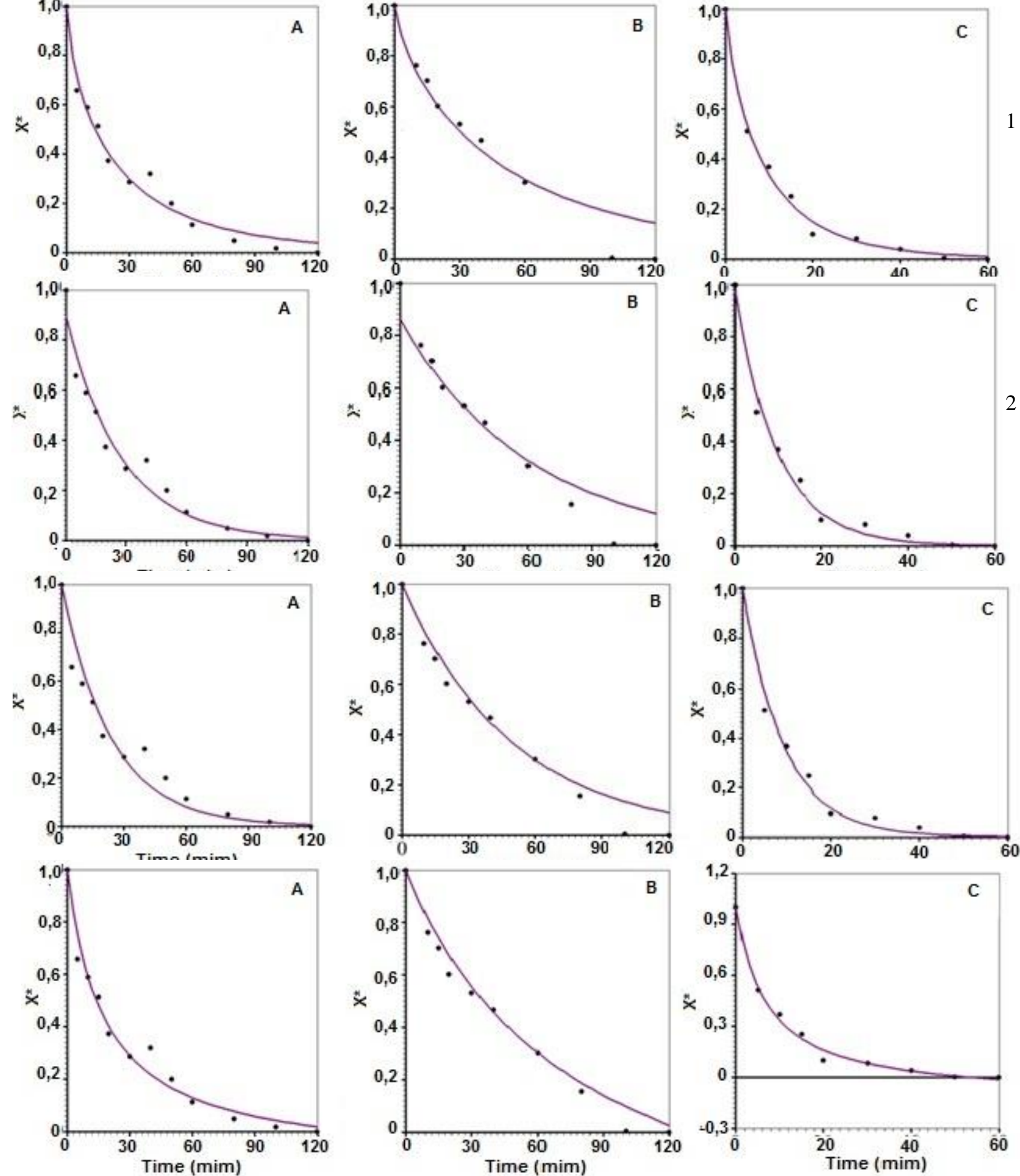

Figure 1. Water obtained in the drying curve of Moringa seeds (Moringa oleifera Lam.) at temperatures of $40(\mathrm{~A}), 50(\mathrm{~B}), 60^{\circ} \mathrm{C}(\mathrm{C})$ adjusted to the model of Page (1); Henderson and Pabis (2); Lewis (3) and Peleg (4)

For the Peleg models (Fig 4C), the statistical values found are considered satisfactory. However, when analyzing the graphical representation of the adjustment to the data, it does 
not present a coherent physical behavior to the study, crossing the field of negative water quantity, before reaching the equilibrium point of the dehydration process. This means that the tested models are not reliable to be used in simulating the drying process of moringa seeds within the temperature range.

Such behavior was also evidenced by Silva (2016) and Pereira et al. (2017b) for the Peleg model, which showed graphical incoherence to the data obtained in the synthetic drying of jackfruit seeds and 'Bud' palm shoots, where the model came to cross the negative water quantity field before reaching the equilibrium point of the drying process.

\section{Chemical determinations in moringa seed flour}

The results obtained by drying moringa seeds under different temperatures are shown in Table 3.

Table 3. Chemical determinations of moringa seed meal obtained at different temperatures

\begin{tabular}{cccccc}
\hline & \multicolumn{3}{c}{ Temperature } & \multicolumn{3}{c}{ Physical and chemical determinations (\%) } \\
\cline { 2 - 6 }$\left({ }^{\circ} \mathrm{C}\right)$ & Proteins & Ashes & Lipids & Moisture & Carbohydrates \\
\hline 40 & $1.90 \mathrm{a}$ & $42.60 \mathrm{~b}$ & $3.18 \mathrm{a}$ & $5.05 \mathrm{a}$ & $47.26 \mathrm{a}$ \\
50 & $1.45 \mathrm{a}$ & $47.94 \mathrm{a}$ & $3.15 \mathrm{a}$ & $4.84 \mathrm{a}$ & $42.62 \mathrm{~b}$ \\
60 & $1.44 \mathrm{a}$ & $46.51 \mathrm{a}$ & $3.21 \mathrm{a}$ & $4.75 \mathrm{a}$ & $44.08 \mathrm{ab}$ \\
\hline
\end{tabular}

The averages followed by the same letter in the same column do not differ statistically from each other, by the Tukey test at the $5 \%$ probability level.

No significant difference $(\mathrm{P}<0,05)$ was observed for the protein content in the moringa seed flour obtained at the different temperatures (Table 3), however a small decrease in these quantitative values was observed due to the increase in temperature, a common behavior in the flour production process with the elevation of temperature. Proteins when subjected to the heat treatment undergo changes in their properties, mainly being destroyed the physiological properties. Tetteh et al. (2019) studying drying methods for M. oleifera found out that sunand oven-dried leaves presented higher glucosinolates contents which are important bioactive compounds for human health.

It was observed a significant difference $(\mathrm{P}<0.05)$ for the ash content in the flour. Flours obtained at the temperatures of 50 and $60{ }^{\circ} \mathrm{C}$ presented the highest percentages (Table 3). The ash percentage is mainly influenced by the fertility of the soil where the plant was cultivated. The high ash content is justified by the high concentration of mineral elements that it contains, with a high concentration of calcium. Pena et al. (2008) and Pedral et al. (2015) found ashes values in moringa leaves lower than those found in this study, of 14,75 and $8,47 \%$, this behavior can be justified by the seed being a drain, where most of the translocated salts in the 
plant are stored. Moringa presented in its constitution minerals essential to the human organism, such as calcium considered one of the most important elements for human growth and development. For example, while 226 grams of milk can deliver 300 to $400 \mathrm{mg}$, moringa leaves can deliver $1000 \mathrm{mg}$ and moringa powder can deliver more than $4000 \mathrm{mg}$ (Gopalakrishinan et al., 2016).

For the lipids content found in the moringa seed flour, no significant difference $(\mathrm{P} \leq 0.05)$ was observed, presenting a small variation of $0,3 \%$ between their values (Table 3 ), for the flours obtained at the temperatures of 40,50 and $60{ }^{\circ} \mathrm{C}$, respectively. Pena et al. (2008) studying quality of passion fruit fiber flour at temperatures of 70,80 and $90{ }^{\circ} \mathrm{C}$, obtained constant values for the lipid content of around 1\%. These values are low when compared to those found in this study. Such behavior can be attributed to the nature of the plant material, where the moringa seed is an almond, thus, rich in vegetable oil content.

There was no significant effect $(\mathrm{P}<0.05)$ on the moisture content of the moringa seed flour obtained at the different temperatures. However, there was a decrease in moisture content as a function of temperature elevation (Table 3). The moisture contents in the flours found in this work are within the limit stipulated by Fernandes et al. (2008) that impose a maximum limit of $14 \%$, since values above the established can form lumps, stimulating the development of molds and yeasts, which ends up reducing the quality of the flour.

For the percentage of carbohydrates found in the moringa seed flour, a significant difference $(\mathrm{P}<0,05)$ was observed, decreasing as a function of temperature increase, reaching $42.62 \%$ in the flour obtained at $50{ }^{\circ} \mathrm{C}$ (Table 3). Borges et al. (2009) studied the achievement and quality of jasmine flour at different temperatures, contrary to the results of this study, with an increase in the percentage of carbohydrates as a function of temperature variation, varying from 58.38 to $61.94 \%$ for temperatures 60 and $70{ }^{\circ} \mathrm{C}$. This condition may have been influenced by the plant material as well as the temperature used in the drying, however the carbohydrate values found in the flours of this study are considered good, indicating a good energy source. The large amount of carbohydrates present in the moringa flour is indicative of a good source of energy (Páramo-Calderón et al., 2019). Thus, the processed moringa seed flour can be used to treat malnutrition problems (Nambiar and Parnami, 2008).

\section{Conclusion}

The studied models presented good statistical results due to the adjustments in the experimental data. The Page model is characterized as the most suitable to simulate the drying kinetics of moringa seeds, based on the coefficients of determination and chi-square. The Peleg model presented a unique graphic behavior, reaching the field of negative water content, before reaching the balance of the dehydration process, indicating that this model cannot be used to simulate the process of drying moringa seeds.

The different temperatures influenced the quality of the flour. The flour obtained at the temperature of $40{ }^{\circ} \mathrm{C}$ presented the best percentages of protein, ash, moisture and carbohydrates. In terms of lipid content, the flour with the best percentages was obtained at temperatures of 50 and $60^{\circ} \mathrm{C}$. 


\section{References}

Abiodun, O. A., Adegbite, J. A., \& Omolola, A. O. (2012). Chemical and physicochemical properties of moringa flours and oil. Global Journal of Science Frontier Research, 12, 12-18.

Anwar, F., Sajid, L., Muhammad, A., \& Anwarul, H. G. (2007). Moringa oleifera: a food plant with multiple medicinal uses. Phytotherapy Research, 21, 17-25. https://doi.org/10.1002/ptr.2023

Borges, A. B., Pereira, J., \& Lucena, E. M. P. (2009). Caracterização da farinha de banana verde. Ciência e Tecnologia de Alimentos, 29, 333-339. https://doi.org/10.1590/S0101-20612009000200015

Fernandes, A. F., Pereira, J., Germani, R., \& Oiano-Neto, J. (2008). Efeito da substituição parcial da farinha de trigo por farinha de casca de batata (Solanum Tuberosum L.). Ciência e Tecnologia de Alimentos, 28, 56-65. https://doi.org/10.1590/S0101-20612008000500010

Gopalakrishnan, L., Doriya, K., \& Kumar, D. S. (2016). Moringa oleifera: A review on nutritive importance and its medicinal application. Food Science and Human. Wellness, 5, 49-56. https://doi.org/10.1016/j.fshw.2016.04.001

Gualberto, A. F., Ferrari, G. M., Abreu, K. M. P., Preto, B. L., \& Ferrari, J. L. (2014). Características, propriedades e potencialidades da moringa (Moringa oleifera Lam.): Aspectos agroecológicos. Revista Verde Agroecologia e Desenvolvimento Sustentável, 9, $19-25$.

Instituto Adolfo Lutz (IAL). (2008). Métodos Físico-Químicos para Análise de Alimentos. $4^{\mathrm{a}}$ Edição. 1st Ed., São Paulo.

Jittanit, W. (2011). Kinetics and temperature dependent moisture diffusivities of pumpkin seeds during drying, Kasetsart Journal: Natural Science, 45, 147-158.

Kashaninejad, M., Mortazavi, A., Safekordi, A., \& Tabil, L. G. (2007). Thin-layer drying characteristics and modeling of pistachio nuts. Journal of Food Engineering, 78, 98-108. https://doi.org/10.1016/j.jfoodeng.2005.09.007

Madureira, I. F., Melo, R., \& Silva Filho, A. J. Q. (2012). Cinética de secagem da polpa do figo-da-india. Revista Brasileira de Produtos Agroindustriais, 14, 345-354. https://doi.org/10.15871/1517-8595/rbpa.v13n4p345-354

Mercali, G. D., Tessaro, I. C., Norena, C. P. Z., \& Marczak, L. D. F. (2010). Mass transfer kinetics during osmotic dehydration of bananas (Musa sapientum, shum.). International Journal Food Science Technology, 2281-2289. https://doi.org/10.1111/j.1365-2621.2010.02418.x

Nambiar, V. S., \& Parnami, S. (2008). Standardization and organoleptic evaluation of drumstick (Moringa oleifera) leaves incorporated into traditional Indian recipes. Trees for Life Journal, 3, 1-7. 
Nóbrega, J. S., Souza, T. A., Souto, L. S., Figueiredo, F. R. A., \& Sá, F. V. S. (2018). Produção de mudas de moringa (Moringa oleífera) sob irrigação com água salina e substratos. Revista Brasileira de Agricultura Irrigada, 12, 3012-3020. https://doi.org/10.7127/rbai.v12n600886

Obando, W. I., \& Ojeda, M. E. O. (2016). Evaluación de producción primaria de la moringa (Moringa oleífera Lamark) en la estación experimental "mutile". Revista Cientifica Interdisciplinaria Investigácion y Saberes, 5, 84-91.

Páramo-Calderón, D. E., Aparicio-Saguilán, A., Aguirre-Cruz, A., Carrillo-Ahumada, J., Hernández-Uribe, J. P., Acevedo-Tello, S., \& Torruco-Uco, J. G. (2019). Tortilla added with Moringa oleifera flour: Physicochemical, texture properties and antioxidant capacity. LWT. 100, 409-415. https://doi.org/10.1016/j.lwt.2018.10.078

Pedral, A. L., Barbosa, J. S., Santos, G. R., Xavier, A. C. R., Arimatéa, C. C., Fontes, A. S., Silva, G. F., \& Barreto, L. C. O. (2015). Caracterização físico-química de folhas da Moringa oleífera desidratadas por secagem convectiva e liofilização. Revista Brasileira de Produtos Agroindustriais, 17, 33-39. https://doi.org/10.15871/1517-8595/rbpa.v17n1p33-39

Pena, R. S., Silva, D. M., Mendonça, N. B., \& Almeida, M. D. (2008). Estudo da secagem da fibra residual do maracujá. Revista Brasileira de Tecnologia Agroindustrial, 2, 1-13. https://doi.org/10.3895/S1981-36862008000100001

Pereira, E. M., Silva, N. J. P., Sousa, H. C., Mattiuz, B. H., \& Silva Filho, C. R. M. (2017b). Technological aspects of obtaining spineless cactus [Nopalea cochenilifera (L.) Salm-Dyck] bud flour after drying. Australian of Journal Crop Science, 11, 1358-1365. http://dx.doi.org/10.21475/ajcs.17.11.10.pne708

Pereira, E. M., Silva, W. P., Gomes, J. P., Silva, C. M. P. S., Formiga, A. S., \& Costa, F. B. (2017a). Empirical models in the description of prickly pear shoot (Nopal) drying kinetics.

Revista Brasieira de Engenharia Agrícola e Ambiental, 21, 798-802.

http://dx.doi.org/10.1590/1807-1929/agriambi.v21n11p798-802

Rodríguez-Pérez, C., Quirantes-Piné, R., Fernández-Gutiérrez, A., \& Segura-Carretero, A. (2015). Optimization of extraction method to obtain a phenolic compounds-rich extract from Moringa oleifera Lam leaves. Industrial Crops and Products, 66, 246-254. https://doi.org/10.1016/j.indcrop.2015.01.002

Silva, F. A. S., \& Azevedo, C. A. V. (2016). The assistat software version 7.7 and its use in the analysis of experimental data. African Journal of Agricultural Research, 11, 3733-3740. https://doi.org/10.5897/AJAR2016.11522

Silva, W. P., \& Silva, C. M. D. P. S. (2016). LAB Fit Curve Fitting Software (Nonlinear Regression and Treatment of Data Program) V 7.2.48 (1999-2015). Available at <www.labfit.net>. Accessed on June 8, 2019.

Sousa, K. A., Resende, O., Chaves, T. H., \& Costa, L. M. (2011). The drying kinetics of forage turnips (Raphanus sativus L.). Revista Ciência Agronômica, 42, 883-892. 
https://doi.org/10.1590/S1806-66902011000400009

Souza, F. M., Pereira, W. E., Dantas, J. S., Nóbrega, J. S., Lima, E. C. S., \& Sá, F. V. S. (2018). Initial growth of Moringa oleifera Lam. as a function of poultry litter doses and granulometry. Pesquisa Agropecuária Tropical, 48, 399-406. https://doi.org/10.1590/1983-40632018v4852447

Tetteh, O. N. A., Ulrichs, C., Huyskens-Keil, S., Mewis, I., Amaglo, N. K., Oduro, I. N., Adarkwah, C., Obeng-Ofori, D., \& Förster, N. (2019). Effects of harvest techniques and drying methods on the stability of glucosinolates in Moringa oleifera leaves during $\begin{array}{llll}\text { post-harvest. } \quad \text { Scientia } \quad H o r t i c u l t u r a e, & \text { 998-1004. }\end{array}$ https://doi.org/10.1016/j.scienta.2018.11.089

Vázquez-León, L. A., Páramo-Calderón, D. E., Robles-Olvera, V. J., Valdés-Rodríguez, O. A., Pérez-Vázquez, A., García-Alvarado, M. A., \& Rodríguez-Jimenes, G. C. (2017). Variation in bioactive compounds and antiradical activity of Moringa oleifera leaves: Influence of climatic factors, tree age, and soil parameters. European Food Research Technology, 243, 1593-1608. https://doi.org/10.1007/s00217-017-2868-4

\section{Copyright Disclaimer}

Copyright for this article is retained by the author(s), with first publication rights granted to the journal.

This is an open-access article distributed under the terms and conditions of the Creative Commons Attribution license (http://creativecommons.org/licenses/by/4.0/). 